\title{
Coping with coopetition-Facing dilemmas in cooperation for sustainable development: The case of the Dutch smart grid industry
}

\author{
Julia Planko (D) | Maryse M.H. Chappin (1D | Jacqueline Cramer | Marko P. Hekkert (1)
}

Copernicus Institute of Sustainable Development, Utrecht University, Utrecht, The Netherlands

\section{Correspondence}

Julia Planko, Copernicus Institute of

Sustainable Development, Utrecht University,

Princetonlaan 8a, Utrecht 3584 CB, The

Netherlands.

Email: julia.planko@hu.nl

\begin{abstract}
This paper is amongst the first to examine coopetition strategy for sustainable development at the network level. Companies who want to successfully implement complex innovative technologies that support sustainable development need to collaborate with other actors of the innovation ecosystem, including their competitors, so that they can develop standards, interoperable products, pool knowledge, and resources and bundle forces to compete against other technologies. Collaboration with competitors brings benefits, but also many risks. We investigated how firms cope with these risks when establishing an innovation ecosystem to implement a new technology in society. We conducted research in the Dutch smart grids sector and explored how these firms minimize inherent risks of coopetition. We found that system-building actors in the Dutch smart grid field not only minimize inherent risks, but from the start of their collaboration they implement so-called enablers to prevent these risks upfront.
\end{abstract}

\section{KEYWORDS}

collaboration, collective system building, coopetition, innovation ecosystem, sustainability technologies, sustainable development

\section{1 | INTRODUCTION}

Sustainable development requires innovative sustainability technologies as well as structural changes of socio-technical systems (Hargadon, 2010; Roome, 2001). To solve or mitigate societal problems such as climate change, environmental pollution, and overuse of finite resources, new socio-technological systems need to be built (Hargadon, 2010; Jacobsson \& Bergek, 2011; Jansen, 2003). For radical innovations that contribute to sustainable development cross-sector collaboration in networks of firms, suppliers, competitors, customers, and universities is important (Melander, 2017). Together, these interorganizational networks can achieve the required systemic change (Heuer, 2011; Josserand, Kaine, \& Nikolova, 2018; Roome, 2001).

The success of an innovating firm, in the case of radical innovation, however, often also depends on the efforts of other actors in the innovation ecosystem, with whom they cocreate products and services, develop interoperable sets of complementary innovations, and bring innovations to the market. In cooperative networks, they combine resources to cocreate products and to shape their innovation ecosystem (Adner \& Kapoor, 2010; Oh, Phillips, Park, \& Lee, 2014). The process of networks strategically creating and shaping their innovation ecosystem is called "collective system building" (Musiolik \& Markard, 2011; Planko, Cramer, Chappin, \& Hekkert, 2016). Key strategic areas in this so-called collective system building are the development and optimization of the new technology, the stimulation of sociocultural changes, and the creation of a market for the technological innovation. Moreover, to accelerate systembuilding processes, the different firm's system-building activities have to be coordinated (Planko et al., 2016). When engaging in collective system building, firms face a profound dilemma: They have to collaborate closely with firms that are their competitors. Firms have to share crucial information with their competitors, and pool resources, in order to develop a technological system with compatible products and services and to create a market for their products. This, however, 
entails many risks, such as knowledge leakage, dependencies, or loss of first-mover advantage.

Rizzi, Bartolozzi, Borghini, and Frey (2013) point out that collaborative networks with the aim of sustainable development can be profitably managed under a systemic perspective, yet, that it is important to understand the conditions that make it possible to gain benefits that outweigh costs, both from a firm and system perspective (Rizzi et al., 2013). We want to understand how networks of firms deal with risks inherent in coopetition when building innovation ecosystems. We therefore explore the conditions that enable collaboration in system-building networks, which we call enablers. We study the enablers of coopetition in system building from a system perspective.

A systematic overview of enablers that reduce the risks for collective system-building actors had not yet been conducted, nor an empirical study on enablers of coopetition at the network level. In our paper, we close this gap.

The aim of this paper is to explore how actors who are building an innovation ecosystem for an emerging sustainability technology minimize the inherent risks of collaborating with competitors. Our research question is as follows: How do actors deal with risks from collaboration for system building?

Previous research on coopetition has generally focused on a firm perspective and firm-centered strategy making, as compared with network-level strategies with the aim to build a prosperous innovation ecosystem, from which all ecosystem actors can benefit. We contribute this network level perspective by looking at collaboration in ecosystems. Moreover, the coopetition literature mainly focused on the risks and benefits and hardly on the enablers. We contribute to the literature by focusing on the enablers and not merely on the risks and benefits. Finally, we contribute to the coopetition literature with our focus on ecosystems that aim to introduce sustainability innovations. We respond to the call for more research on sustainability coopetition, "to explore the tensions between competitive strategy and cooperation in striving towards sustainability" (Christ, Burritt, \& Varsei, 2017, p. 1029).

In the next section, we introduce the theory on this. Then we describe the Dutch smart grid sector, which is our empirical context. Subsequently, we explain our methods followed by a description and discussion of our results. We end with a conclusion and avenues for future research.

\section{2 | COOPETITION AT THE NETWORK LEVEL}

The coopetition literature addresses the issue of the simultaneous cooperation and competition between different independent organizations-termed "coopetition" (Bengtsson \& Kock, 2014; Walley, 2007). Competition often takes place close to the customer, in areas such as value-added business practices, price, service, and quality, whereas cooperation takes place in activities more distant from customers, such as R\&D, standard setting, developing a new market, and removing external obstacles and threats (Bengtsson \& Kock, 2000; Liu, 2013).

Coopetition can be narrowly defined as a dyadic relationship between two rival firms or broadly defined as a relationship between multifirm alliances who simultaneously cooperate and compete with each other, regardless of whether their relationship is horizontal or vertical (Bengtsson \& Kock, 2014; Wilhelm, 2011). Taking on the broad definition, scholars have analyzed coopetition in the context of business networks, value nets, and supply chains (Bouncken \& Kraus, 2013; Fernandez, Le Roy, \& Gnyawali, 2014; Tidström, 2013; Walley, 2007). But these papers do not focus on networklevel outcomes.

Nevertheless, coopetition at the network level is important for knowledge-intensive, dynamic, and complex fields, particularly for high-technology industries due to their networked nature (Gnyawali \& Park, 2009; Park, Srivastava, \& Gnyawali, 2014; Ritala \& Hurmelinna-Laukkanen, 2009; Ritala \& Sainio, 2014). Especially for breakthrough technological innovations that not only change existing technologies or make them obsolete but also encounter very high technological and market uncertainty (Bouncken \& Kraus, 2013; Ritala, 2012). That is why we study coopetition in the context of innovation ecosystems, taking on the broad definition of coopetition.

\section{1 | Dilemma of collaboration with competitors}

Coopetition is potentially beneficial, but also includes major risks for a firm (Ritala, 2012; Ritala \& Hurmelinna-Laukkanen, 2009). These benefits and risks have been identified before. Because identifying benefits and risks is not the aim of the paper, an overview of those is provided in Appendix $A$.

To reduce risks arising from collaboration and to increase potential benefits, it is important to manage coopetition processes both at the firm level and the network level (Dahl, 2013; Osarenkhoe, 2010; Park et al., 2014). So far, little research has been done on how competitors manage coopetition processes at the network level to reduce risks from collaboration and increase its potential benefits (Bengtsson \& Kock, 2014; Dahl, 2013; Fernandez et al., 2014).

Firms who coopete in networks can create conditions that enable both competitive and collaborative relationships to coexist (Osarenkhoe, 2010). These conditions help to overcome difficulties and reap the advantages of collaboration; they are enablers of collaboration with competitors (Chin, Chan, \& Lam, 2008; Ojasalo, 2008). "Enablers" mitigate risks inherent in coopetition and thereby enable the collaboration between competitors to take place. Few authors have assessed these conditions (Christ et al., 2017) and these who have (e.g. Bengtsson \& Kock, 2000; Chin et al., 2008), have assessed them from a firm-perspective, as opposed to from a network-perspective.

\section{2 | Overview of enablers mentioned in coopetition literature}

The coopetition literature therefore does not show a systematic overview of enablers for collective system building, to stimulate coopetition for sustainable development. Some coopetition scholars mention critical success factors, enabling conditions or key factors of coopetition. We clustered them and describe them below. 


\subsection{1 | Trust}

Coopetition scholars describe that trust enhances cooperative behavior, stimulates knowledge exchange, reduces potential for tensions, and generally affects work group functioning positively (Bengtsson \& Kock, 2000; Bouncken \& Kraus, 2013; Chin et al., 2008; Dahl, 2013; Fernandez et al., 2014; Liu, 2013; Osarenkhoe, 2010; Park et al., 2014; Ritala \& Hurmelinna-Laukkanen, 2009). Moreover, a disenabler related to trust is mentioned: "general distrust." General distrust, for example, concerns about capturing rents or loss through knowledge leakage, impedes cooperation and value creation (Tidström, 2013; Zineldin, 2004)

\subsubsection{Common vision and goals}

The literature describes that a clear, strong vision and common goals are needed in a coopeting network to link up different organizations and their interests; these are based on mutual objectives and complementary needs. Voluntary and mutual agreements aimed at achieving common goals and strategic objectives together can be based on trust or stipulated in formal agreements, such as informal contracts (Bengtsson \& Kock, 2000; Chin et al., 2008; Ojasalo, 2008; Osarenkhoe, 2010; Zineldin, 2004).

\subsection{3 | Goal alignment}

The literature points out that networks should pursue collective strategies for value generation. The different firms' interests need to be aligned toward a common network objective. Common ground should be developed and diverging interests mitigated (Bouncken \& Kraus, 2013; Gnyawali \& Park, 2009; Liu, 2013; Osarenkhoe, 2010). Moreover, the coopetition literature mentions "insufficient goal alignment" as a disenabler: Conflicting goals and objectives among partner firms and difficulty to align operations at the alliance level with the firm's long-term goals may lead to a failure of the collaborative initiative, especially when it is managed poorly (Liu, 2013; Walley, 2007; Zineldin, 2004).

\subsection{4 | Equal power distribution}

The distribution of control and power between the partners is of importance for the performance of an alliance. Mutuality or equity in risk and contribution is important for the success of the alliance (Bengtsson \& Kock, 2000).

\subsection{5 | Project management}

Good project management is crucial for effective collaboration and can also avoid misunderstanding and conflicts (Ojasalo, 2008).

Clearly defined responsibilities of each partner enable the different partners to know what to expect (Zineldin, 2004).

\subsection{6 | Knowledge and risk sharing}

Whereas knowledge sharing is critical for the cooperative part of the relationship, the sharing of risks is crucial to minimize losses (Chin et al., 2008).

\section{3 | EMPIRICAL CASE: THE DUTCH SMART GRID SECTOR}

To study coopetition in the context of complex high-technology industries that contribute to sustainable development, in which actors collaborate to build up a prosperous innovation ecosystem around their new sustainability technology, the empirical case of the Dutch smart grid sector was chosen. It was chosen because it is an emerging industry in which actors collaborate closely with other actors all along the supply chain, including their direct competitors, to build up a favorable ecosystem. Coopetition is a good strategy when new markets need to be created and consumers need to be educated about the benefits and functions of the new product and when standards need to be set to develop complex interoperable solutions (Bouncken \& Kraus, 2013; Gnyawali \& Park, 2009; Ritala, 2012; Ritala \& Sainio, 2014). These characteristics also apply to our case.

A smart grid is an electricity network combined with an IT network, which is adapted to the introduction of renewable energy sources. Essentially, smart grids are many highly intertwined technologies. For example, when solar panels produce "too much" electricity, a specially designed software will automatically increase the temperature of a "smart fridge", or use another smart device, to use up the excess energy and prevent the grid from being supplied with too much energy (Planko, Chappin, Cramer, \& Hekkert, 2017). The development and implementation of smart grids requires intensive collaboration between actors, such as universities, governmental actors, and user groups but also direct competitors (Planko et al., 2016). They need to bundle forces to create interoperable products and markets for these products. Yet they also compete for market share when the market is developed. This makes the smart grid sector interesting to study coopetition. We focus on the Dutch smart grid sector specifically because it is one of the front-runners in Europe, with close interaction from not only companies but also by policy makers, knowledge institutions, and user groups.

\section{4 | METHOD SECTION}

To answer our research question, we conducted a single embedded case study in the Dutch smart grids sector (see above).

In a prestudy, we first identified the most important networks (six) of the Dutch smart girds sector, in which companies collaborate to build the ecosystem as well as the key actors of these networks. These networks include competitors and other actors along the value chain and comply with the broad definition of coopetition (Bengtsson \& Kock, 2014; Wilhelm, 2011).

All key actors were approached for an interview, and almost all of them agreed to be interviewed. In the end, 17 interviews were conducted. We do not have the impression that there is a bias in this 
response and we have key actors with different roles in these networks, such as chairman, project manager, or member of the board of directors (Appendix B). This provided us with a broad picture from the different perspectives. Moreover, we realized that we reached saturation, because the final interviews did not reveal new insights.

We conducted semistructured face-to-face interviews. Each interview lasted 60-100 min. The general topic of the interviews was collective system building for a new sustainability technology and the management of system-building networks. One part of the interview specifically addressed the risks and benefits of collaboration with competitors in system building.

Our initial aim was to assess what risks were perceived for collaborating for each of the system-building activities (Planko et al., 2016). In the first interviews, it became clear that interviewees did not perceive collaboration as risky because they had put enablers in place that reduced inherent risks upfront. That made us focus in the interviews much more on the process of collaboration and enablers. We did not ask closed questions in which we mentioned specific enablers identified in the coopetition literature. Instead, we asked open questions, so not to influence interviewees and also to avoid socially desirable answers.

Interviews were recorded, transcribed, and analyzed with Atlas.ti software. The analysis consists of two main steps. We first coded the benefits and risks mentioned by the interviewees. This was done on the basis of the benefits and risks we identified in the literature (see Appendix A). We compared these results with literature. As explained, the risks were reduced, but the outcomes with respect to the benefits reassured us that the coopetition we research was in that respect similar to earlier studies. In the second step, we focused on the identification of the enablers they mentioned increasing benefits or mitigating risks. We used the enablers that we identified in the literature as a first coding scheme. But it was clear that more enablers were mentioned that did not fit these enablers. The new enablers were clustered based on the underlying mechanisms. This resulted in a new framework of enablers.

\section{5 | FINDINGS AND DISCUSSION: ENABLERS OF COOPETITION AT NETWORK LEVEL}

Actors in the Dutch smart grid sector use a variety of enablers to mitigate risks, or even prevent them. Some enablers are implemented upfront to avoid risks from coopetition, others are implemented during the process of building up the innovation ecosystem. We will first describe the enablers for collective system building at the network level, which are in line with the existing coopetition literature, and then we will discuss the new ones and the one different from existing literature. The findings are illustrated by supporting examples and quotes from the interviews (respondent number is indicated between square brackets).

\section{1 | Trust development}

Almost all interviewees (13/17) stressed the importance of trust for collective system building. This is in line with the coopetition literature where it has already been mentioned as an enabler. Sufficient trust enables collaboration between competitors and enables them to develop system resources based on jointly created knowledge. In the smart grids field, "there's a high level of trust, people understand they need each other, there's no hiding back information" [11].

Trust was seen as an essential enabler for ecosystem building, as it is necessary for actors to share valuable information about their innovation and their firm's strategy, in order to be able to generate a shared vision for the sector, which is the prerequisite for coordinated collaborative system building. "[...] in the beginning it really is about trust, so do you trust each other to share a vision where you want to go, and what your development path is. You need to be open to show your strategy partly, and things that you do, but if you trust each other - well, then you can do it" [17].

\section{2 | Common vision and goals}

All interviewees mentioned that a common vision is necessary for this type of collaboration. This is in line with the coopetition literature. Half of the interviewees even elaborated intensively on the importance of a common vision and jointly set goals to give direction to the collaboration and the building of the ecosystem. "A collaborative system requires a common goal" [13]. The development of a common vision is crucial to enable benefits for collaboration to develop innovative technologies and establish a supportive business ecosystem. "A common vision is necessary to form standards and to enable large scale implementation" [6]. The common vision gives direction to the development of the sector. Having a common vision allows firms to "develop in the same direction" [13] and to develop industry standards, which enable them to generate interoperable products and network resources. Based on this vision, networks develop their network objectives.

Common objectives were regularly reviewed and if necessary adjusted to the further-developed innovation ecosystem.

\section{3 | Goal alignment}

In line with the coopetition literature, the majority of interviewees (10/17) also mentioned the necessity to align goals and to prevent goal conflicts. The fact that smart grid actors develop their vision together facilitates that they will be able to align their company goals to it. "It's about vision. It's about how you see this vision as part of your strategy" [12]. To enable goal alignment, the different interests and different company goals need to be acknowledged. "Actors should try to understand each other's interests and take these into account" [3].

\section{4 | Investment into the collaboration}

A few interviewees (3/17) mentioned that companies are more actively involved if they invest money and in-kind contributions into the network. "Because we want to have them really actively involved, we ask: 'What is your main interest? And what would you invest in?' [...] And if people say: 'Well, we want to go to a certain route, then 
they also should say, 'we're going to invest money into the development.' So they will be more committed" [13]-"Commitment from companies is important, they should be willing to invest" [3]. Investment into the collaboration was used as a specific mechanism to reduce opportunistic behavior. For example, one network had at one occasion many members, of which a few seemed to extract knowledge rather than contribute. To reduce this opportunistic behavior, a substantial membership fee was introduced. This made the less motivated companies leave the network, but the motivated ones stayed, which lead to better goal alignment and higher commitment within the network.

The enabler investment into the collaboration is not yet mentioned as such in the coopetition literature. The literature does mention "risk sharing" as a success factor (Chin et al., 2008). However, it is not explicitly stated that this risk sharing means investing money into the network, nor is it linked to increasing commitment and better goal alignment. A plausible explanation could be that in most interorganizational collaborations empirically studied so far, the number of collaborating firms is already clear in advance, and there is a plainly defined purpose. That is, there is no "fluid" networkforming and goal-defining phase, in which information is already generated and exchanged. And in supplier network collaborations, new firms only join the network if a transaction will be made (e.g., intermediary products delivered), which inherently requires an investment on their part, and a "membership fee" is not necessary.

\section{5 | Clear boundaries to information sharing}

About one third of the interviewees (5/17) stated that an essential enabler for knowledge exchange is that there are very clear boundaries to information sharing. As also indicated in the literature, knowledge exchange is necessary for successful coopetition (Chin et al., 2008). The same applies to the development of a business ecosystem. Actors know that to generate a common vision, to standardize technology and cocreate compatible products and services, it is essential to exchange detailed information on their innovative ideas. "Of course there's tension where you have to share knowledge and interests of your own company with your competitor. But all the partners understand that we cannot aggregate business if we don't collaborate" [17]-"From the beginning on they should have clear boundaries in terms of exchanging information" [10]-"Make explicit what you should share with each other and what you shouldn't share" [17]. They make agreements such as "what is discussed in the project stays in project" [11]. Knowing that the information stays within the agreed-on boundaries reduces the perceived risk of knowledge leakage.

This enabler is not yet mentioned in the coopetition literature. Chin et al. (2008) do mention the relevance of "knowledge sharing," they do not explain how this knowledge can be exchanged safely while reducing the risk of knowledge leakage. One reason can be that previous studies did not focus on coping with risks. Our study does and shows that they solve this by clearly specifying what to share. Moreover, it can be explained by our empirical context. The fact that we study an innovation ecosystem with not just one technology but a complex set of intertwined technologies might make it even more important to make clear agreements about this beforehand.

\subsection{Careful composition of partners in pilot projects}

About one fourth of the interviewees (4/17) mentioned another mechanism, which enables knowledge exchange on the system level while minimizing the risk of knowledge leakage to competitors. In a network that developed knowledge and conducted different pilot projects, for each pilot project, a constellation of actors that were not direct competitors was chosen. Although there were direct competitors in the network as a whole, two direct competitors did not work in the same pilot project. This enabled the firms within each pilot project to share knowledge relatively openly. "In this network there were some direct competitors from other energy suppliers and we arranged it in a way within the network that in every pilot project, we had only one supplier. So that there is some collaboration on the higher, conceptual level where you exchange your insights and ideas; but within one pilot we could be open on the innovations even when there is commercial interest" [8].

At the end of the pilot projects, outcomes of the pilot studies were shared among all members, leaving out the crucial details. This enabled coopeting firms in a network to exchange knowledge, learn from each other and develop a vision, while at the same time not having to expose one's core knowledge to direct competitors.

Also, this enabler for coopetition at the network level was not yet mentioned in the coopetition literature. A plausible explanation is that the level of observation in most empirical studies was at the firm level, and not at the network level. From a firm-level perspective, the question is if the firm should participate in the collaboration or not and what the inherent risks would be. In contrast, from a network-level perspective, the question is how to enable a sector-wide knowledge exchange between competitors, without them being afraid of losing commercially valuable information to competitors.

\section{7 | Clear boundaries to joint technology development}

Although all interviewees agreed that strong collaboration is necessary for technology development and optimization, half of them (8/17) pointed out that the development of commercially viable products can and should be conducted individually. When it comes to final product development, they prefer to do this individually, or only with complementary technology producers, but not with competitors. "In my experience, with development of commercial products there was a line. On most system-building aspects you can collaborate, but when it comes to commercial product development it is different" [8]. This is possible when there is an open infrastructure with an industry-wide standard. "Commercially viable products can be developed on the open infrastructure by individual parties" [1].

The coopetition literature does not yet mention this enabler. The reason could be that previous studies have focused on dyadic relationships, supply chains, or less complex technologies, while we study the 
case of an emerging ecosystem that aims to develop a complex set of intertwined technologies.

\section{8 | Neutral entity in charge of coordination}

Half of the interviewees (8/17) mentioned that having a neutral entity in charge of coordinating the interorganizational collaboration is important. It reduced the perceived risk of opportunistic behavior by partners because a neutral organization or "neutral person" would have no interest in pushing their own agenda or deciding on network objectives which would mainly serve their company's objective. "He should not be part of the discussion, he should have an objective view on things" [10]-"I think that is because we are not a commercial party, it is accepted that we take that role [of a coordinator]. We can steer discussions and encourage decisions, without being questioned by other network members" [13] - "I was chosen [as network coordinator] because I am independent. I will not take sides and I try to balance the interests of the parties" [1].

A neutral entity in charge of coordination seems necessary for system-building networks, but was not mentioned in existing literature. The literature, however, mentions that good project management is indispensible for coopetition (Ojasalo, 2008; Zineldin, 2004), especially to enable knowledge exchange and the provision of shared information, but does not refer to a neutral entity.

A plausible explanation is that in established industries, collaboration has a clearly defined purpose from the start of the collaboration, like the delivery of an existing product or service or an incremental product innovation. The collaborative goals are a result of the companies' goals. In system building, often the opposite is the case: First, the vision for the sector is designed, and then company goals have to be adjusted to these system goals. Therefore, it is important to have a neutral leader, who can be trusted not to have a hidden agenda or push the sector's development in a direction that mainly serves his own firm.

\section{9 | Clear collaboration structures}

Half of the interviewees (8/17) mentioned that clear collaboration structures enabled the collaboration. Clear governance structures and coordination mechanisms were essential for the network's functioning, as they enabled decision making and efficient coordination of activities. This enabler is not about what knowledge and resources are exchanged, but how they are exchanged. One interviewee pointed out that more important than the specific type of governance mechanisms chosen was that collaboration structures were introduced to the network and that these structures were clear to all network participants. " A good set of rules is important to make it work in a smooth way. Because if you don't have a clear set of rules, decisions will not be taken" [15].

The coopetition literature does mention it is important to have clear responsibilities (Zineldin, 2004), but does not yet mention this enabler of clear collaboration structures. A plausible explanation is that the empirical cases so far used, such as dyadic relationship and supplier networks, have less actors involved or a focal company in charge, so in those cases, the collaboration structure is more or less predefined, and it is much more about clarifying responsibilities, whereas here in our empirical setting, it is about setting clear collaboration structures.

\subsection{0 | Creation of a "common playing field"}

Almost half of the interviewees (7/17) elaborated on the need to find the right balance between collaboration to bundle forces and align developments and competition to increase innovative solutions. If technology development activities are not aligned and knowledge is not shared, it means that sometimes "the wheel is reinvented" [14] and that resources are used inefficiently. On the other hand, the downside of highly aligning technology development would mean a loss of innovativeness, as many potential solutions would be neglected from the start. The smart grid actors did not experience that their collaboration slowed down innovation. However, they also stated that it was important to keep developing innovative solutions independently, to generate a variety of ideas. "It is good to have competition, because it will generate many alternative technology solutions, so the best solution can be delivered to end users and society. [...] On the other hand, if many initiatives are working on the same thing, than it is not efficient and a lot of money is wasted. But transition is not a straight line" [8]. Smart grid actors stated that better than deciding at a central institution in which direction to develop was to "create a space" [7] in which companies and organizations can develop their ideas, innovations, and products. "It is not possible to come up with a 'grand scheme of collaboration to realize the energy transition', because players don't understand all aspects this transition entails. We cannot already define the course from the start. We [facilitating organization] are trying to create space; space for everybody who wishes to make a contribution to the sustainable energy transition. We must enable them to work together" [8]. To create this space, a common vision and industry-wide standards are necessary, and the institutional environment needs to be shaped, for example, to achieve enabling regulations. A "common playing field" [5] was created.

The creation of a common playing field enables the coopeting actors to find the right balance between bundling their forces and generating manifold innovative technological solutions. This enabler has not been mentioned yet in the coopetition literature; a plausible explanation for this is that compared with the empirical cases so far studied where collaborating units usually have a fixed goal, system building is an uncertain adventure. At the start of the collaboration, goals are not yet defined, and it is not yet determined which firms and other actors will become collaboration partners.

\subsection{1 | Fair collaboration between big and small firms}

To build up a new ecosystem successfully, big and small companies need to collaborate. The big ones have power and resources, and the small ones are often the generators of innovative ideas but do not have sufficient power and resources to implement them. About one fourth of the interviewees (4/17) explained that in the smart grids sector, actors were aware that small companies are necessary for system-building processes, but that they cannot invest equal amounts 
of resources as their bigger collaborators. Bigger companies invest more into the network collaboration, in terms of money and in-kind contributions. This unequal contribution of resources is compensated by unequal power distribution. In return for making higher investments, the big companies get more decision-making power. "In the general assembly, if you are a platinum member, you get five votes [instead of one vote as a regular member]" [12]. All partners consider this situation to be an acceptable solution. "It is difficult to put a monetary value on it, but our co-operation with the big companies was really, really valuable, we [as a small start-up] gained a lot from it" [16].

Actors find it much more important to have fair distribution of power and control, rather than that it is equal. "For the smaller ones it's less interesting to have governance rights, so they mainly contribute at content level. It's about being fair how you organize projects. [...] A lot of small firms are not directly part of the main consortium, they cannot invest like that, but you take them along your development paths, and you make sure that the costs and benefits are shared in a fair way" [17].

This finding differs from the coopetition literature, in which equal power distribution is emphasized. It is described that equity in risk and contribution is important for the success of the collaboration. However, in our empirical case, we found that actors understood that they needed big and small companies in their collaboration for system building and that small companies were not able to contribute as many resources-financially and in-kind-as big ones. A plausible explanation for this difference is the empirical focus of the study, which suggested this enabler, were alliances with equally sized actors, for example,

TABLE 1 Overview of enablers derived from empirical case compared with existing coopetition literature

\begin{tabular}{|c|c|c|}
\hline $\begin{array}{l}\text { Enablers derived } \\
\text { from empirical case }\end{array}$ & $\begin{array}{l}\text { In line with } \\
\text { theory/new/different }\end{array}$ & $\begin{array}{l}\text { Mentioned by } \\
\text { interviewee \# }\end{array}$ \\
\hline Trust development & In line with theory & $\begin{array}{c}1,2,3,6,7,8,10,11 \\
12,13,15,16,17\end{array}$ \\
\hline $\begin{array}{l}\text { Common vision and } \\
\text { goals }\end{array}$ & In line with theory & $\begin{array}{l}1,2,3,4,5,6,7,8,9 \\
10,11,12,13,14 \\
15,16,17\end{array}$ \\
\hline Goal alignment & In line with theory & $\begin{array}{l}1,3,7,6,9,10,11,12 \\
13\end{array}$ \\
\hline $\begin{array}{l}\text { Investment into the } \\
\text { collaboration }\end{array}$ & New & $8,12,16$ \\
\hline $\begin{array}{l}\text { Clear boundaries to } \\
\text { information sharing }\end{array}$ & New & $2,9,10,14,17$ \\
\hline $\begin{array}{l}\text { Careful composition } \\
\text { of partners in pilot } \\
\text { projects }\end{array}$ & New & $8,9,11,16$ \\
\hline $\begin{array}{l}\text { Clear boundaries to } \\
\text { joint technology } \\
\text { development }\end{array}$ & New & $1,4,5,8,11,12,15,17$ \\
\hline $\begin{array}{l}\text { Neutral entity in } \\
\text { charge of } \\
\text { coordination }\end{array}$ & New & $2,3,6,7,8,9,10,13$ \\
\hline $\begin{array}{l}\text { Clear collaboration } \\
\text { structures }\end{array}$ & New & $3,4,6,7,8,9,11,15$ \\
\hline $\begin{array}{l}\text { Creation of a "common } \\
\text { playing field" }\end{array}$ & New & $5,6,10,11,12,14,17$ \\
\hline $\begin{array}{l}\text { Fair collaboration } \\
\text { between big and } \\
\text { small firms }\end{array}$ & Different & $1,12,16,17$ \\
\hline
\end{tabular}

for R\&D or complementary services, who are similar in size and have equal resources. They can make equal contributions and expect equal power distribution. In system-building networks that is not always the case.

\section{6 | CONCLUSION}

Little research had been done on how to reduce risks of interorganizational coopetition from a network-level perspective. We conducted an empirical study of the Dutch smart grid sector to investigate how system-building actors deal with the dilemma of collaboration with competitors. We found that system-building actors implement several enablers to increase the benefits and reduce the risks of coopetition and they often prevent risks upfront. They strategically set up their collaboration in such a way that they minimize or even prevent risks and increase the benefits of coopetition.

To conclude, in collective system building, actors design collaboration with competitors upfront in a way that facilitates collaboration and alleviates its inherent risks. They strategically use combinations of enablers to cope with the dilemma of collaboration versus competition. These enablers are trust development, investment into the collaboration, common vision and goals, goal alignment, clear boundaries to information sharing, clear boundaries to joint technology development, neutral entity in charge of coordination, clear collaboration structures, creation of a "common playing field," careful composition of partners in pilot projects, and fair collaboration between big and small firms (Table 1).

The key contribution of this paper is that it examines coopetition strategy for sustainable development at the network level. We contribute to the coopetition literature the empirical setting of system building - actors all along the supply chain collaborating to establish an innovation ecosystem around a technological innovation for sustainable development. Even though the perceived benefits are fairly similar to the dyadic coopetition studies, the newly identified enablers can be attributed to this specific setting. The studied innovation ecosystem does not deal with just one technology but a complex set of intertwined technologies for which the end goals are not fixed nor clear. Moreover, not only technology is emerging but also the networks and collaborations are (fluid network forming).

These findings are interesting for management scholars in general, as industries are changing and new ways of working are required, which are based on interorganizational collaboration in ecosystems.

The paper also makes a practical contribution. Practitioners who want to build up a favorable ecosystem around their innovative technology can use the described enablers to strategically minimize or even prevent coopetition risks and reap more benefits from it.

A limitation of this paper is that we studied only one case, the case of the Dutch smart grids system. We tried to offset this by interviewing the most important key actors of the sector, covering the whole innovation ecosystem, and conducting in-depth interviews. For future research, our findings could be tested in more emerging industries, to increase generalizability. Moreover, we found some indications that different enablers and risks occur in different phases of industry emergence, but not enough to make claims about it. This would be interesting to investigate in further research. 


\section{ORCID}

Julia Planko (D) https://orcid.org/0000-0002-3505-9219

Maryse M.H. Chappin (D) http://orcid.org/0000-0001-6247-1930

Marko P. Hekkert (D) http://orcid.org/0000-0003-0570-5117

\section{REFERENCES}

Adner, R., \& Kapoor, R. (2010). Value creation in innovation ecosystems: How the structure of technological interdependence affects firm performance in new technology generations. Strategic Management Journal, 31, 306-333. http://doi.org/10.1002/smj

Bengtsson, M., \& Kock, S. (2000). "Coopetition" in business networks-To cooperate and compete simultaneously. Industrial Marketing Management, 29(5), 411-426. http://doi.org/10.1016/S00198501(99)00067-X

Bengtsson, M., \& Kock, S. (2014). Coopetition-Quo vadis? Past accomplishments and future challenges. Industrial Marketing Management, 43(2), 180-188. http://doi.org/10.1016/j.indmarman.2014.02.015

Bouncken, R. B., \& Kraus, S. (2013). Innovation in knowledge-intensive industries: The double-edged sword of coopetition. Journal of Business Research, 66(10), 2060-2070. http://doi.org/10.1016/j.jbusres.2013. 02.032

Chin, K.-S., Chan, B. L., \& Lam, P.-K. (2008). Identifying and prioritizing critical success factors for coopetition strategy. Industrial Management \& Data Systems, 108(4), 437-454. http://doi.org/10.1108/ 02635570810868326

Christ, K. L., Burritt, R. L., \& Varsei, M. (2017). Coopetition as a potential strategy for corporate sustainability. Business Strategy and the Environment, 26(7), 1029-1040. http://doi.org/10.1002/bse.1967

Dahl, J. (2013). Conceptualizing coopetition as a process: An outline of change in cooperative and competitive interactions. Industrial Marketing Management http://doi.org/10.1016/j.indmarman.2013.12.002, 43, 272-279.

Fernandez, A. S., Le Roy, F., \& Gnyawali, D. R. (2014). Sources and management of tension in co-opetition case evidence from telecommunications satellites manufacturing in Europe. Industrial Marketing Management, 43(2), 222-235. http://doi.org/10.1016/j. indmarman.2013.11.004

Gnyawali, D. R., \& Park, B. (. R.). (2009). Co-opetition and technological innovation in small and medium-sized enterprises: A multilevel conceptual model. Journal of Small Business Management, 47(3), 308-330. http://doi.org/10.1111/j.1540-627X.2009.00273.x

Hargadon, A. (2010). Technology policy and global warming: Why new innovation models are needed. Research Policy, 39(8), 1024-1026. http://doi.org/10.1016/j.respol.2010.05.009

Heuer, M. (2011). Ecosystem cross-sector collaboration: Conceptulizing an adaptive approach to sustainability governance. Business Strategy and the Environment, 20(November), 211-221. http://doi.org/10.1002/ bse.673

Hung, S.-W., \& Chang, C.-C. (2012). A co-opetition perspective of technology alliance governance modes. Technology Analysis \& Strategic Management, 24(7), 679-696. http://doi.org/10.1080/09537325. 2012.705120

Jacobsson, S., \& Bergek, A. (2011). Innovation system analyses and sustainability transitions: Contributions and suggestions for research. Environmental Innovation and Societal Transitions, 1(1), 41-57. http:// doi.org/10.1016/j.eist.2011.04.006

Jansen, L. (2003). The challenge of sustainable development. Journal of Cleaner Production, 11(3), 231-245. http://doi.org/10.1016/S09596526(02)00073-2

Josserand, E., Kaine, S., \& Nikolova, N. (2018). Delivering sustainability in supply networks: Achieving networked multi-stakeholder collaborations. Business Strategy and the Environment, 27(5), 605-611. http:// doi.org/10.1002/bse.2065
Liu, R. (2013). Cooperation, competition and coopetition in innovation communities. Prometheus, 31(2), 91-105. http://doi.org/10.1080/ 08109028.2013.818788

Loebecke, C., Van Fenema, P. C., \& Powell, P. (1999). Co-opetition and knowledge transfer. The Database for Advances in Information Systems, 30(2), 14-25. http://doi.org/10.1145/383371.383373

Luo, Y. (2007). A coopetition perspective of global competition. Journal of World Business, 42(2), 129-144. http://doi.org/10.1016/j. jwb.2006.08.007

Melander, L. (2017). Achieving sustainable development by collaborating in green product innovation. Business Strategy and the Environment, 26(8), 1095-1109. http://doi.org/10.1002/bse.1970

Musiolik, J., \& Markard, J. (2011). Creating and shaping innovation systems: Formal networks in the innovation system for stationary fuel cells in Germany. Energy Policy, 39, 1909-1922. https://doi.org/ 10.1016/j.enpol.2010.12.052

Oh, D. S., Phillips, F., Park, S., \& Lee, E. (2014). Innovation ecosystems: A critical examination. Technovation, 54, 1-6. http://doi.org/10.1016/j. technovation.2016.02.004

Ojasalo, J. (2008). Management of innovation networks: A case study of different approaches. European Journal of Innovation Management, 11(1), 51-86. http://doi.org/10.1108/14601060810845222

Osarenkhoe, A. (2010). A coopetition strategy-A study of inter-firm dynamics between competition and cooperation. Business Strategy Series, 11(6), 343-362. http://doi.org/10.1108/17515631011093052

Park, B.-J. (. R.)., Srivastava, M. K., \& Gnyawali, D. R. (2014). Walking the tight rope of coopetition: Impact of competition and cooperation intensities and balance on firm innovation performance. Industrial Marketing Management, 43(2), 210-221. http://doi.org/10.1016/j. indmarman.2013.11.003

Planko, J., Chappin, M. M. H., Cramer, J. M., \& Hekkert, M. P. (2017). Managing strategic system-building networks in emerging business fields: A case study of the Dutch smart grid sector. Industrial Marketing Management, 67, 37-51. http://doi.org/10.1016/j.indmarman.2017.06.010

Planko, J., Cramer, J. M., Chappin, M. M. H., \& Hekkert, M. P. (2016). Strategic collective system building to commercialize sustainability innovations. Journal of Cleaner Production, 112, 2328-2341. http:// doi.org/10.1016/j.jclepro.2015.09.108

Ritala, P. (2012). Coopetition strategy-When is it successful? Empirical evidence on innovation and market performance. British Journal of Management, 23, 307-324. http://doi.org/10.1111/j.14678551.2011.00741.x

Ritala, P., \& Hurmelinna-Laukkanen, P. (2009). What's in it for me? Creating and appropriating value in innovation-related coopetition. Technovation, 29(12), 819-828. http://doi.org/10.1016/j. technovation.2009.07.002

Ritala, P., \& Sainio, L.-M. (2014). Coopetition for radical innovation: Technology, market and business-model perspectives. Technology Analysis \& Strategic Management, 26(2), 115-169. http://doi.org/10.1080/ 09537325.2013 .850476

Rizzi, F., Bartolozzi, I., Borghini, A., \& Frey, M. (2013). Environmental management of end-of-life products: Nine factors of sustainability in collaborative networks. Business Strategy and the Environment, 22(8), 561-572. http://doi.org/10.1002/bse.1766

Roome, N. (2001). Conceptualizing and studying the contribution of networks in environmental management and sustainable development. Business Strategy and the Environment, 10(2), 69-76. http://doi.org/ 10.1002/bse. 276

Tidström, A. (2013). Managing tensions in coopetition. Industrial Marketing Management http://doi.org/10.1016/j.indmarman.2013.12.001, 43, 261-271.

Walley, K. (2007). Coopetition: An introduction to the subject and an agenda for research. International Studies of Management and Organization, 37(2), 11-31. http://doi.org/10.2753/IMO0020-8825370201 
Wilhelm, M. M. (2011). Managing coopetition through horizontal supply chain relations: Linking dyadic and network levels of analysis. Journal of Operations Management, 29(7-8), 663-676. http://doi.org/ 10.1016/j.jom.2011.03.003

Zineldin, M. (2004). Co-opetition: The organisation of the future. Marketing Intelligence \& Planning, 22(7), 780-790. http://doi.org/10.1108/ 02634500410568600
How to cite this article: Planko J, Chappin MMH, Cramer J, Hekkert MP. Coping with coopetition-Facing dilemmas in cooperation for sustainable development: The case of the Dutch smart grid industry. Bus Strat Env. 2019;28:665-674. https://doi.org/10.1002/bse.2271

\section{APPENDIX A}

\section{BENEFITS AND RISKS OF COOPETITION}

In the coopetition literature, several benefits and risks of collaboration with competitors are mentioned. We have clustered and summarized these benefits and risks, which can occur at the firm level or at the inter-organizational level (network level).

TABLE A1 Benefits of coopetition identified from the coopetition literature

\begin{tabular}{|c|c|}
\hline Level & Benefits \\
\hline Firm level & $\begin{array}{l}\text { Risk and costs sharing: Firms can spread the risks and costs involved in various activities such as product development and } \\
\text { standardization; this increases the incentive to take risks and be proactive in product development. They can share costs for } \\
R \& D \text {, for developing new products and of entering new markets } \\
\text { Uncertainty reduction: Coopetition reduces the costs, risks, and uncertainties of new product development } \\
\text { Access to resources and knowledge: Firms gain access to additional know-how, skills, competence, market knowledge, reputation, } \\
\text { and other resources. A company can thereby use its limited resources in the most efficient way, which potentially improves the } \\
\text { firm's innovation }\end{array}$ \\
\hline
\end{tabular}

Based on Bengtsson and Kock (2000, 2014), Bouncken and Kraus (2013), Gnyawali and Park (2009), Hung and Chang (2012), Liu (2013), Loebecke, Van Fenema, and Powell (1999), Luo (2007), Osarenkhoe (2010), Ritala (2012), Ritala and Hurmelinna-Laukkanen (2009), Ritala and Sainio (2014), Tidström (2013), Walley (2007), and Zineldin (2004). 
TABLE A2 Risks of coopetition identified from the coopetition literature

Level
Risks level
Opportunistic behavior by partners: Firms who collaborate with competitors are exposed to the risks of knowledge loss to
partners and partners simply copying ideas, product innovations, or core competences. Furthermore, bigger partners can exploit
a weaker partner's interest or take over the cooperation. The risk of opportunistic behavior by partners is especially high when
cooperative agreements are loosely governed and structured.
Knowledge leakage: Coopeting firms risk unintended leakage of confidential knowledge to partners. Moreover, they risk sharing
core knowledge and not gaining sufficient knowledge in return. This may lead companies to restrict knowledge sharing.
Intra-firm goal conflict: Tension may arise between the goals of firms and goals of the network. Coordinating and controlling the
cooperation commitments demand a considerable amount of time and effort, which may lead to neglect of an organization's
core business. Managers might feel role conflicts as an employee of the firm and as a network member.
Loss of control: Firms who coopete give up control over resources, they lose freedom of decision making, and their dependency
on the network limits flexibility. Firms may lose competitive innovation and become dependent on other firms. They can lose
autonomy and power. In particular, smaller firms can become depended on bigger ones.
Power imbalance: Asymmetrical power bases can lead to a loss of competitive advantage, dependencies, and knowledge loss,
usually for the smaller firm. Power and dependence can be a source of conflict.
Insufficient returns: Firms need to invest time and money into the collaboration, which may not yield the required return. Or one
of the parties might not get enough of a return.
Reduced innovativeness: Firms that collaborate with competitors are less innovative; "group thinking" may
hamper their creativity and innovation efforts.
Coordination difficulties: Difficulty to coordinate the coopeting networks may lead to failure of the
collaborative initiative.

Based on Bouncken and Kraus (2013), Gnyawali and Park (2009), Liu (2013), Loebecke et al. (1999), Luo (2007), Osarenkhoe (2010), Park et al. (2014), Ritala and Hurmelinna-Laukkanen (2009), Ritala and Sainio (2014), Tidström (2013), Walley (2007), and Zineldin (2004).

\section{APPENDIX B}

TABLE B1 Roles and network membership of interviewees

\begin{tabular}{|c|c|c|}
\hline Interviewee number & Network & Role in network \\
\hline 1 & C & Network manager \\
\hline 2 & $\mathrm{~F}$ & Network manager \\
\hline 3 & $E$ & Network manager/chairman \\
\hline 4 & $E$ & Member \\
\hline 5 & $E$ & Network manager/project manager \\
\hline 6 & $E$ & Member \\
\hline 7 & $\mathrm{D}$ & Network manager \\
\hline 8 & $\mathrm{~F}$ & Member (project leader of a pilot project) \\
\hline 8 & A & Member \\
\hline 9 & A & Network manager/project manager \\
\hline 10 & B & Network manager \\
\hline 11 & B & Member \\
\hline 11 & A & Member (former network manager) \\
\hline 12 & C & Member (program line leader) \\
\hline 12 & $\mathrm{D}$ & Member \\
\hline 13 & C & Member (program line leader) \\
\hline 13 & $\mathrm{~F}$ & Member \\
\hline 14 & B & Network manager/chairman \\
\hline 15 & $\mathrm{D}$ & Member \\
\hline 16 & $\mathrm{~F}$ & Member \\
\hline
\end{tabular}

